\title{
Management of Construction Projects in Vietnam: An Activity Theory Analysis
}

\author{
Michael Er
}

\begin{abstract}
The analysis of managing construction projects is often reviewed using the iron triangle of time, cost and quality. Researchers in the field of project management have called for new paradigms to be applied to analysing projects. The research in this paper uses Activity Theory as a lens of interpretation to compare the management of construction projects in Vietnam against practices used in developed countries. The research focuses on the work Activity of construction management professionals and the mediating forces that differentiate building in Vietnam. The research found mediating factors such as the physical environment where work was taking place, the low cost of labour and the culture characteristics of loss of face and approach to site safety, played a significant role in the construction Activity in Vietnam. An emergent theme highlighted by using the Activity Theory paradigm is an interconnected relationship between mediating elements in an Activity System.
\end{abstract}

Index Terms-Activity theory, construction management, Vietnam.

\section{INTRODUCTION}

The management of construction projects is an area well associated with project management. Time, cost and quality are widely used as criteria in the assessment of project success in construction projects [1], [2]. Several researchers in the area of project management have developed new models of analysis however time, cost and quality often remain at the core [3]. Several studies into the construction industry in Vietnam make use of project management concept to initiate their research, again with much of the discussion involving aspects of Time, Cost or Quality [4]-[8].

Research using the platform of time, cost and quality as the key performance indicator basis, or part-of, have however, been criticised as being limited, only taking into account an economic perspective [9]. Baccarini [10] noted that construction projects are complex. As projects become more complex new models and techniques for analysing and managing projects is required [11]. Researchers in the area of Project Management called for new paradigms [12]-[15] suggesting that these new paradigms should provide a "lens through which one may view the field" of project management [16].

Cicmil et al. [17] suggests a greater emphasis in researching the actuality of projects through thematic studies of experiences of practitioners. "Researching the actuality of

Manuscript received November 11, 2016; revised December 23, 2016.

Michael Er is with University of Technology Sydney, Australia (e-mail: Michael.er@uts.edu.au). projects means focusing on social processes and how practitioners think in action, in the local situation of a living present," (p. 676)

Researchers in the area of project management could make use of contemporary research methods which links theory and practice [18] with [19] proposing the use of Activity Theory as an appropriate framework of analysis.

The research in this paper reports on a pilot study that considers the actualities of managing construction projects in Vietnam interpreted through the lens of Activity Theory. The case study compares the management of large, complex construction projects (such as high-rise development) in a developed country such as Australia or United Kingdom against that in the developing (or peripheral) country of Vietnam. A brief overview of Activity Theory is next considered.

\section{ACTIVITY THEORY}

Activity Theory was initially developed by Russian psychologists in the 1920's and 1930's and is the study of what humans 'do' or human activity. Engestrom [20] has developed a popular model used by Activity Theory researchers (see Fig. 1: Engestrom's model of Activity Theory). Activity Theory shifts the research paradigm from one that is focused on the outcomes of a project (such as the resulting time, cost and quality) to one that examines the work Activity. In this model the Subject is the group that the researcher is studying and can be either an individual or a group depending on the level of granularity that is required. The theory dictates that an Object drives human activity. The Object is the motivation for 'doing' (what the Subject of research wants to achieve) and that this work (the Activity) is the unit of analysis. The Activity is represented by the line between the defined Subject and Object with the Outcome the actual result of the undertaken Activity.

In the case of a construction project, the Object would be the completed building that the Subject has in mind (planned), the Activity is the effort the focus Subject undertakes in order to build the specific construction project and the Outcome would be the actual completed building.

Tools and the Community mediate the way an Activity is undertaken. Tools, often referred to as artifacts, are created by humans and offer signs to the Subject that assists in directing them towards a particular action. Tools can take various forms depending upon the context of the study; they may range from instruments, signs, procedures, or machines, to language, methods, laws, and forms of work organisation. 


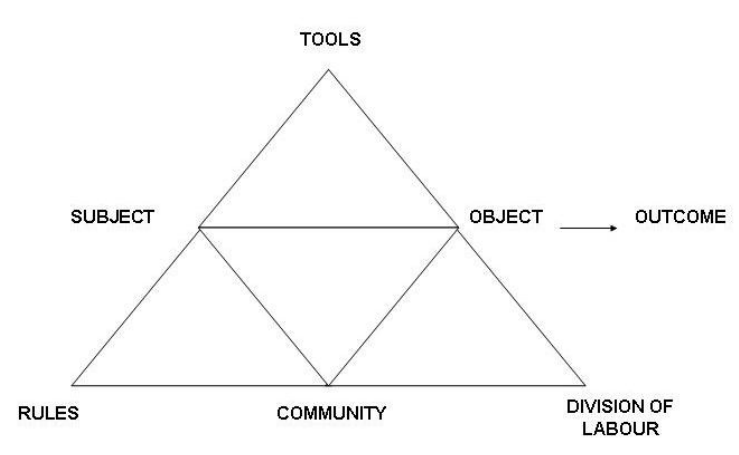

Fig. 1. Engestrom's model of activity theory.

A second influence which mediates an Activity is the Community. The influence that the Community of Practice has upon an Activity is applied through Rules to which the Subject adheres. These Rules are implicit and explicit governance which direct the Subject. Explicit Rules are easily identified as documented codes of practice or standards which govern the requirements of workers. Implicit Rules are the norms which the Subject accepts as requirements (informal procedures as well as the social relationship between the Subject and the Community), often derived from other more experienced workers.

The final component Engestom's model of Activity theory is the Divisions of Labour which represents the collaborators that the Subject works with in the Activity but which are not the subject of research. For example, in the construction scenario, the researched Subject might be the construction staff of the contracting firm and the Divisions of Labour would be the developer, design consultants, suppliers, sub-contractors etc that interact in the project.

Er and Lawrence [21] suggest that there are other factors that mediate an Activity such as the Physical Environment and the Situational Context. The Physical Environment influences construction work in that individual construction projects (as with all projects) are unique. Different locations require individual design to meet the physical attributes of the build site and customised build methods and management to complete the project. Access to specific material is another example of the influence that Physical Environment has on Activity. If construction materials are readily available in the location then these materials may be preferred due to availability of material and the reduced cost in transporting these materials. Situational Context refers to the situation that the Subject is working such as operating in an adversarial atmosphere opposed to a collaborative / cooperative one. Another example of how an Activity may vary is if a project is behind program, the approach that the Subject group will take will most likely differ to one in which has little urgency.

\section{MethodOLOGY}

The research in this paper describes the pilot case study and initial findings of a study on the management of construction projects in Vietnam. The research is qualitative in nature as the investigation considers themes of project management interpreted through the lens of Activity Theory.

To capture the actuality of managing construction, the collection of data combined semi-structured interviews construction management professional working in Vietnam and observations from a site visit to a large multistorey high-rise construction project located in Ho Chi Minh City, Vietnam. The construction professionals interviewed for the research were typically senior "expatriate" workers (see Table I: Interviews) with substantial experience in both Vietnam and a developed country such as Australia or the United Kingdom. Transcriptions of digitally recorded interviews were desensitised so interviewees are not identifiable and subject to a thematic analysis to identify common themes in line with Activity theory.

TABLE I: INTERVIEWS

\begin{tabular}{llll}
\hline \hline $\begin{array}{l}\text { Construction } \\
\text { Management } \\
\text { Professional }\end{array}$ & $\begin{array}{l}\text { Construction } \\
\text { Experience }\end{array}$ & $\begin{array}{l}\text { Experience } \\
\text { Vietnam }\end{array}$ & Construction Role \\
\hline CPM1 & $20+$ & 6 & $\begin{array}{l}\text { Construction } \\
\text { Manager } \\
\text { CPM2 }\end{array}$ \\
CPM3 & $25+$ & $20+$ & $\begin{array}{l}\text { Surveyor and PM } \\
\text { Project Manager } \\
\text { CPM4 }\end{array}$ \\
\hline \hline
\end{tabular}

The construction site visit was organised and supervised by both the project manager and site manager. This project consisted of basement car park, 3 high-rise towers and 4 floors of retail podium. The site visit provided a first-hand view of construction in Vietnam and an opportunity to observe the mediating factors that influenced the management of work Activity on a large construction project.

Using Activity Theory as a lens of interpretation places the Construction Management Professionals as the Subject, the planned construction works as the Object and the Outcome as the completed buildings. The research examines the management of building projects by the Construction Management Professionals (the Activity) and the forces that mediate their Activity.

\section{FINDINGS AND DISCUSSION}

The underlying construction technology used on the construction site visited in Vietnam was similar to that used in modern construction projects in places such as Australia and the United Kingdom. The works in progress at the time of the site visit consisted of a large excavation of the entire building footprint and reinforced concrete structure to ground level. Two tower cranes were being utilised to assist with the movement of materials around the site to the specific points of work.

The Outcome of the construction work in Vietnam appears to be similar to that in developed countries with the existence of many high-rise buildings in Ho Chi Minh City.

Although the construction technology (Tools) and the Outcome appear to be similar to that in developed countries, the work Activity on the construction projects in Vietnam (the way work was done) was distinctly different. The main mediating factors that influenced a difference in the management of construction projects identified by the pilot research included the elements outlined below. 


\section{A. Difference - The Environment}

The natural environment in Ho Chi Minh City resulted in several conditions that impacted the Activity. For example, CPM1 noted that they had to pile up to 80 metres on his current project as the foundations were not very stable and meant that they had to allow for a long in-ground program. CPM4 noted that the rainy season also created planning issues as it "could rain for weeks non-stop". The project CPM4 was working on decided to delay the construction program to ensure a start at the end of the rainy season and to maximise a continuous construction program.

CPM4 also noted that additional works were sometimes needed based on the quality of materials. For example, "the sand over here for rendering is a lot more coarser so we have to render and then plaster. In Australia the sand is finer and we can just paint the render."

All the Construction Management Professionals talked about pouring concrete at night and a combination of environmental conditions that required this process. Firstly, CPM4 and CPM1 both noted that curing concrete during the heat of the day in Ho Chi Minh City would result in cracking. Additionally, CPM1 mentioned that there were government restrictions on the movement of trucks during daylight hours meaning concrete pours are not possible during the daytime.

\section{B. Difference - Local and International Clients}

The Construction Management Professionals noted a difference in the work Activity depending on whether the client was either Vietnamese or international. CPM1 provided an insight into the differences in Activity depending on the client noting: "We've got 5 forty storey plus towers on a development but I don't really get involved because it's a Vietnamese client, Vietnamese meetings, but in the same development there is the international hotel and Mace are the PM, Arups are the designers, Atkins are the architects, Aurecon are the MEP, again they're more western type clients, so I go in as a facilitator for our guys and to make sure it all goes smoothly". (CPM1) That is, the Division of Labour (collaborators that the Construction Management Professionals work with) changes from local Vietnamese consultants to international depending on the client.

Working with international clients and consultants affected the Activity by changing the expectation on quality. In these cases the Construction Management Professionals agreed that the level of quality is much higher. To meet their expectations on quality the client would "bring expatriates to supervise works or use international contractors". (CPM2)

The use of expatriate supervision increased the level of quality however it also meant that the construction costs were also significantly higher. CPM2 suggested that using expatriate supervision or international contracting firms posed a cost escalation of up to $35 \%$.

\section{Difference - Cheap Labour and the Consequences for Construction Activity}

Irrespective of the client being local or international, labour in Vietnam is considered to be cheap. The low cost of labour and trades in general was highlighted by CPM2 who noted that as a comparison an electrician "in Australia might cost $\$ 100$ an hour, in Singapore it might be like $\$ 100$ a day and in somewhere like Vietnam its $\$ 100$ per month." The Construction Management Professionals agreed that the cost of this labour (collaborators) has a major impact on the construction Activity in several ways.

The first impact of cheap labour was observed on the construction site visited. The installation of a large footing block for the building was being installed and the Site Manager noted that the cranes were lifting reinforcing steel into position prior to pouring the concrete however there was a substantial section of the reinforcing that was being installed as the crane did not have coverage. The reinforcing steel was instead being installed by hand and the contractor had hired a "couple of hundred more men" to do this work. Similar scenarios as above was considered to be common by the Construction Management Professionals and reveals that when there is a problem the solution employed in Vietnam is to hire more labour. CPM 1 noted that "labour is so cheap here and you can throw labour at things like any issue that comes up."

The above scenario also revealed that there was a lack of organisation on construction projects. The management of the project should have ensured that the tower crane installed had the capacity to effectively deliver material to the required areas around site. The impact of fundamental errors in the planning and execution of construction works are however softened by the use of large amounts of cheap labour.

The lack of organisation was noted by CPM2 describing the management of a well known project in Ho Chi Minh City - "the interesting thing is that the structure was topped out before anything else was done. It was like, we've done the structure what should do we do now... Let's rough in some MEP... they didn't know what to do next. Hadn't thought through what to do next." (CPM2)

According to CPM4 the low cost of labour permits general inefficiency. He outlines the case that in Australia the hanging (installation) of a door would be undertaken by a single tradesperson whereas in Vietnam there would be at least 3 or 4 people involved. He noted that "labour is so cheap here that they're just no efficient... Labour in Australia is expensive so we have to be efficient."

Although labour workforce in Vietnam large and cheap it is also uneducated. CPM4 noted that he had over 600 workers on his site at the time of the interview and "none would even qualify as a first year apprentice". He further stated that the labourers on his construction project did not have any education and could not even read or write.

All of the Construction Management Professionals noted that the labour force were transient, mainly coming from rural areas. A common thought was that the labourers would plant their crops and then come to the city to find labouring work. The transient nature of the labour also made it difficult to train and maintain a skilled workforce. CPM3 summed up the itinerate nature of the workforce by saying "traditionally the bulk of labour in third world are itinerate, so they are not educated, a lot of the time farmers... they come from the countryside, they sow their crops and then the men go to the city... Harvest time is a big thing, you loose most of your men because the go back for the harvest." CPM4 agreed stating that the labourer's "life is in the home town, not here (in the city). This is just like filling in the gap until the rice is ready to 
harvest."

Having a large but highly unskilled workforce meant that a large number of supervision was deployed to ensure work was completed to an acceptable level. CPM3 noted that on the project he worked on they "had a team of about 120 people in our site office (in Vietnam) overseeing the work and in Australia you would have half that... The worker (In Australia) is better educated and he won't do the stupid things." (CPM3)

CPM4 highlighted the extreme level of supervision by outlining the process for painting a wall that required 6 hold points (inspections and approvals) for the work. This included when the wall is prepared, installation of plaster-coat finish, second coat of plaster, sealer, first paint coat and second paint coat. In Australia the painter would "just do it" with out supervision and an inspection on completion.

Despite the large number of supervisors used on construction projects in Vietnam, the Construction Management Professionals agreed the quality of the finished construction was relatively low. CPM4 noted that he was "heavy on supervision - that's how I control quality", yet despite the supervision he continues to "have massive defect lists."

\section{Difference - Quality of Finish (Outcome)}

As alluded to above, it was agreed by the Construction Management Professionals that the quality of finish acceptable in Vietnam was comparatively low. CPM3 noted that "The level of expectation of finish is much lower" for clients and final purchasers of units in Vietnam as compared to Australia. CPM2 went further questioning not just the quality of the finishes but also the structure of the building stating that "they put up buildings but it will be interesting to see what they look like in 10 years time."

The poor quality associated with the finished buildings in Vietnam could be a symptom of the general acceptance by the client of a lower quality product.

\section{E. Difference - Contractual Agreement}

Generally, a contract is a formal document that outlines the agreed scope of work for a contractor or sub-contractor and terms such as the duration in which the work will be completed and the payment for works (consideration), penalties if works are not completed in time etc. Breaches in contract performance was noted as commonplace on construction projects in Vietnam by the Construction Management Professionals.

All the Construction Management Professionals provided first-hand experiences in which alternatives to the agreed work where implemented by the contractor of sub-contractor. The non-conforming alternative would be forced upon the client with the hope that they would eventually get worn down and agree to the sub-standard work / material. CPM1 noted that "If they agree to something and then (later) they realise they can't then they'll dig their heels in and just say they can't, you say you agreed to it but they say they can't, but you agreed to it, but we can't... to me the general attitude is 'I know we signed it but that's crazy, why would anyone think we can do that - but you signed it - well they should have known'."

A strong theme that became salient form interviews was that the cultural issue associate with "loosing face" was often a source of breaches in contracts. CPM2 stated that the Vietnamese "just don't want to say no. They understand very well the negotiation and bargaining and so forth to get the job" but will agree to perform works knowing that it is not possible. CPM4 also noted that in some of the cases he had encountered the contractors would agree to works and have no technical idea on what to do, only coming to the agreement as the Vietnamese negotiating did not want to look unintelligent.

\section{F. Difference - Safety}

The level of precautions to ensure the safety of workers on construction sites in Vietnam were generally far lees than that provided in developed countries. CPM2 noted that "safety and organisation on site is the big difference" between developed countries and Vietnam. CPM3 believed that lack of safety was a cultural issues that impacted construction Activity noting that "there is a feeling up there (in Vietnam) that safety just gets in the way of getting work done".

An example of poor safety measures was observed while on the site visit. A trench was being excavated to allow for the installation of large stormwater pipes. Where the excavator was digging there were men at the bottom cleaning out loose ground. The trench was over 2 meters deep and no shoring was installed to prevent collapse. Further, there were no barriers to prevent other workers falling into the trench. While observing the work a passing worker did fall in. The worker managed to crawl back out of the trench, seemingly unhurt however no action to prevent another fall was taken.

The lack of concern for safety was pointed out by CPM4 who found that often in discussions with the contractors and sub-contractors would not price in safety measures into their contract price. They believed that the additional costs associated with safety would mean they "wouldn't get the job". A second consideration is that there is a lack of concern expressed by the workers for safety measures. The lack of concern could also be a consequence of the limited knowledge of construction related risks.

\section{CONCLUSION}

The research detailed in this paper interprets the work of Construction Management Professionals using the platform of Activity Theory. Examining the management of construction projects using this paradigm provides a holistic view of the work Activity and connectivity between mediating elements. For example, in a traditional review of a construction project, cheap labour would be identified as an impact factor upon cost and related to time and quality. For example, in the case of a delay issue on site and to maintain the same level of quality the management team have the option of increasing the amount of labour with minimal impact on the cost of the project.

The unit of analysis in Activity Theory is the Activity and identify mediating factors such as Tools, the Community of Practice (Rules and Division of Labour - Collaborators) as well as the Environment. In the pilot case study, the low cost of labour was identified as a mediating force in the way the construction work Activity was done. A closer examination of 
cheap labour, as a Collaborator, reveals a much more complex relationship between the Activity and Division of Labour. As a mediating force cheap labour provides an inexpensive backup to issues but it also propagates poor organisation of projects (similar findings to that in a traditional analysis). The cheap labour is however poorly educated with the effect of a poor quality of finish and is relatively inefficient. Subsequently more labour is required than would be using a better-educated, higher skill level worker. Further, the majority of labour is transient making it difficult to train and maintain skilled workers. The low skill-set of workers on construction sites in Vietnam necessitates a large supervision workforce also increasing the cost of the project.

An emergent theme that materialised from the research found that other mediating influences (such as the acceptance of a lower quality finish by clients or the lack of safety on the build site) have a reciprocal relationship with the attributes of the cheap labourer. This emergent theme should be further investigated in future research.

\section{REFERENCES}

[1] C. Langston. (2012). Comparing international construction performance. [Online]. Available: http://epublication.bond.edu.au/sustainable development/150

[2] S. Kärnä and J. M. Junnonen, "Benchmarking construction industry, company and project performance by participants' evaluation," Benchmarking: An International Journal, vol. 23, no. 7, pp. 2092-2108, 2016.

[3] A. P. Chan and A. P. Chan, "Key performance indicators for measuring construction success," Benchmarking: An International Journal, vol. 11, no. 2, pp. 203-221, 2004.

[4] L. D. Nguyen, S. O. Ogunlana, and D. T. X. Lan, "A study on project success factors in large construction projects in Vietnam," Engineering, Construction and Architectural Management, vol. 11, no. 6, pp. 404-413, 2004.

[5] N. D. Long, S. Ogunlana, T. Quang, and K. C. Lam, "Large construction projects in developing countries: A case study from Vietnam," International Journal of Project Management, vol. 22, no. 7, pp. 553-561, 2004.

[6] L. L. Hoai, Y. D. Lee, and J. Y. Lee, "Delay and cost overruns in Vietnam large construction projects: A comparison with other selected countries," KSCE Journal of Civil Engineering, vol. 12, no. 6, pp. 367-377, 2008.

[7] F.Y.Y. Ling and H. N. Tran, "Undesirable project management practices adopted to achieve project outcomes: A case study of Vietnam," International Journal of Project Organisation and Management, vol. 4, no. 2, pp. 153-170, 2012.

[8] T.P. Nguyen and N. Chileshe, "Revisiting the construction project failure factors in Vietnam," Built Environment Project and Asset Management, vol. 5, no. 4, pp. 398-416, 2015.

[9] C. Ngacho and D. Das, "A performance evaluation framework of construction projects: insights from literature," International Journal of Project Organisation and Management, vol. 7, no. 2, pp. 151-173, 2015.

[10] D. Baccarini, "The concept of project complexity - A review. International Journal of Project Management," vol. 14, no. 4, pp. 201-204, 1996.

[11] T. Williams, "The need for new paradigms for complex projects," International Journal of Project Management, vol. 17, no. 5, pp. 269-273, 1999.

[12] T. Browning, "A conceptual framework for tackling knowable unknown unknowns in project management," Journal of Operations Management, May 2014

[13] F. Salum, D. Amaral, S. Silva, and L. Almeida, "Can agile project management be adopted by industries other than software development?" Project Management Journal, vol. 45, no. 3, pp. 21-34, 2014.

[14] T. Brady and A. Davies, "Governing complex infrastructure developments: Learning from successful megaprojects," International Symposium for Next Generation Infrastructure, Wollongong, Oct. 1-4, 2013.

[15] M. Bosch-Rekveldt, Y. Jongkind, H. Mooi, H. Bakker, and A Verbraeck, "Grasping project complexity in large engineering projects: The toe (technical, organizational and environmental) framework," International Journal of Project Management, vol. 29, no. 6, pp. 728-739, 2011.

[16] A. J. Shenhar and D. Dvir, "Project management research-the challenge and opportunity," Project Management Journal, vol. 38, no. 2, p. 93, 2007.

[17] S. Cicmil, T. Williams, J. Thomas, and D. Hodgson, "Rethinking project management: researching the actuality of projects," International Journal of Project Management, vol. 24, no. 8, pp. 675-686, 2006.

[18] S. Sankaran, N. Drouin, and R. Müller, "The need for using new research approaches in project management," in Proc. the PMI Research and Academic Conference, vol. 31, 2013.

[19] G. A. John and A. Ganah, "Activity theory perspective for project management research in the built environment," Project Management Development-Practice and Perspectives, p. 104, 2016.

[20] Y. Engestrom, "Activity theory as a framework for analyzing and redesigning work. Ergonomics," vol. 43, no. 7, pp. 960-974, 2000.

[21] M. Er and E. Lawrence, "Using activity theory to examine information systems for supporting mobile work," in Proc. the 24th bled eConference eFuture: Creating Solutions for the Individual, Organizations and Society, vol. 1, pp. 517-529, 2011.

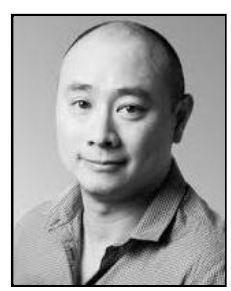

Michael Er was born in Australia, in 1969. He was graduated from a bachelor of building from the University of NSW, a graduate diploma in IT, a masters in information technology and a $\mathrm{PhD}$ in computer science from the University of Technology Sydney.

$\mathrm{He}$ is currently a senior lecturer in the Faculty of Design Architecture and Building at the University of Technology Sydney.

$\mathrm{He}$ has over 20 years professional experience in construction project manager and management consulting. His published research encapsulates information systems, innovation, project management, education and the application of activity theory. 